\title{
Analisa dan Perancangan Website Media Sosial Untuk Komunitas Tari Dengan Metode Prototyping
}

\author{
Al Hadid Ammash \\ Program Studi Sistem Informasi \\ Institut Informatika Indonesia \\ alhadidammash@gmail.com
}

\author{
Raymond Sutjiadi \\ Program Studi Teknik Informatika \\ Institut Informatika Indonesia \\ raymond@ikado.ac.id
}

\author{
Timothy John Pattiasina \\ Program Studi Sistem Informasi \\ Institut Informatika Indonesia \\ temmy@ikado.ac.id
}

\begin{abstract}
Abstrak - Informasi adalah sesuatu yang selalu dibutuhkan ketika setiap pengguna internet melakukan browsing. Informasi tersebut bisa berupa artikel, musik, foto, dan juga video. Dalam dunia tari, informasi sangat mempunyai pengaruh yang besar dalam berkembangnya setiap penari. Website adalah salah satu cara penari untuk mendapatkan informasi berupa konten video atau artikel yang dapat mereka akses dan digunakan untuk bertukar informasi dengan penari yang lain baik lokal atau internasional. Dengan adanya website yang mempunyai ruang lingkup lebih spesifik akan membantu untuk penari tersebut lebih efisien dalam saling bertukar informasi. Website dengan berbasis media sosial akan sangat membantu dalam melakukan komunikasi kepada setiap pengguna di dalamnya. Dalam penilitian ini akan menggunakan metode prototyping, supaya website yang dibuat akan lebih user friendly karena perancangan website akan melibatkan calon pengguna dalam menentukan desain dan fitur yang akan digunakan.
\end{abstract}

Kata Kunci: Metode Prototyping, Dunia Tari, Website Media Sosial, Informasi, Konten Video

\section{PENDAHULUAN}

Website merupakan teknologi yang dipakai kebanyakan orang di dunia, bahkan bisa dikatakan sebagai kebutuhan dalam kehidupan sehari-hari di zaman modern seperti sekarang ini. Website diakses oleh banyak kalangan, dari anak-anak sampai orang dewasa sekalipun. Mayoritas orang melakukan pencarian informasi dengan cara mengakses website untuk mendapatkan informasi yang bisa didapat secara relevan dan berasal dari banyak sumber, termasuk di dalam hal hobi dan profesi. Hobi dan profesi yang akan dibahas di sini adalah dalam ruang lingkup dunia seni, terkhusus di dunia seni tari.

Setiap penari banyak yang melakukan pencarian informasi melalui website, baik itu informasi berupa video atau berupa artikel. Informasi yang mereka dapatkan dapat dijadikan sebuah inspirasi dalam pembuatan karya baru yang akan mereka ciptakan. Selain itu melalui website, penari juga bisa mempublikasikan karyanya secara lebih mudah agar dapat diapresiasi oleh para pencinta dunia tari. Akan tetapi untuk saat ini tidak banyak media website yang bisa mewadahi kebutuhan komunitas para penari tersebut.

Dalam penelitian ini akan dibuat sebuah website sebagai wadah yang bisa membantu para penari untuk bisa berbagi informasi satu dengan yang lain berupa sebuah video atau artikel yang akan mereka buat sehingga bisa menghasilkan banyak karya yang nantinya bisa dijadikan sebuah aset (portofolio) bagi setiap penari dan mampu membuat dunia seni semakin dihargai dan dikenal. Adapun dalan website tersebut mencakup tentang tautan sebuah video, informasi berupa artikel, dan informasi berupa acara-acara yang berhubungan dengan dunia tari, serta bisa digunakan sebagai media para penari untuk bisa bertukar informasi atau diskusi untuk membahas sebuah topik dalam bentuk forum online yang mampu membuat para penari bisa memiliki wawasan tambahan dalam dunia tari.

\section{METODOLOGI PENELITIAN}

A. Definisi Tari

Tari adalah ungkapan perasaan jiwa manusia yang diungkapkan melalui gerak ritmis yang indah dan diiringi musik. Menurut manfaatnya tari dibedakan menjadi 2, yaitu:

- Sebagai hiburan, sifatnya penikmat saja/menghibur saja dan tidak perlu ada persiapan. Hiburan dapat berupa: tarian, music, lawakan.

- Sebagai komunikasi, yaitu melalui gerak-ruang-waktu yang ada padanya yang membawa misi/pesan-pesan sebuah tarian tertentu untuk bisa dipahami oleh penimatnya. Yang dimaksut ruang dan waktu adalah ruang gerak.

Tari merupakan alat ekspresi ataupun sarana komunikasi seseorang seniman kepada orang lain (penonton/penikmat). Sebagai alat ekspresi tari mampu menciptakan untaian gerak yang dapat membuat penikmatmya peka terhadap sesuatu yang ada dan terjadi di sekitarnya. Sebab, tari adalah sebuah ucapan, pernyataan dan ekspresi daam gerak yang memuat komentar-komentar mengenai realitas kehidupan yang bias merasuk di benak penikmatnya setelah pertunjukan selesai. 


\section{B. Forum}

Forum internet merupakan fasilitas yang tersedia di internet, dan penggunanya dapat berdiskusi. Forum berbasis internet ini sudah dikenal sejak tahun 1995, dan fungsinya mirip bahkan lebih baik dari papan buletin dan milis internet yang sudah ada sejak tahun 1980-an [1]. Perasaan komunitas virtual sering muncul pada forum-forum yang memiliki anggota tetap. Teknologi, permainan komputer, dan politik merupakan tema paling populer yang menjadi pokok bahasan forum internet, tetapi masih banyak lagi topik-topik lainnya.

Para anggota forum ini yang biasa dikenal dengan Komunitas Virtual memiliki hak yang lebih baik, misalnya kemampuan untuk menyunting kirimannya sendiri, memulai topik, mengontrol pengaturan dan akses ke profil pengguna lain. Di dalam forum dikenal juga sebutan administrator forum. Seorang administrator forum memiliki kemampuan untuk menyunting, menghapus, memindahkan atau melakukan perubahan terhadap topik yang ada di forum. Administrator umumnya juga memiliki kemampuan untuk menutup forum, mengganti peralatan forum, mengganti kulit secara global, memodifikasi forum, dan memblokir, menghapus atau menambah anggota dalam forum.

Pada dasarnya forum memiliki aturan dan etiket yang di tetapkan oleh penyedia forum atau mediator, misalnya:

- Aturan posting, sebelum posting akan pertanyaan atau komentar, biasakan mencari terlebih dahulu. Fasilitas search sudah tersedia. Pertanyaan ataupun komentar anda mungkin sudah pernah dibahas atau dijawab, komentar sebaiknya sesuai dengan halaman yang sedang di bahas.

- Aturan komunitas, berhubung forum merupakan suatu komunitas maka bantulah orang lain. Berikan masukan ketika anda mengerti akan topik yang sedang di bahas atau feedback terhadap masukan yang anda dapat apakah membantu atau tidak.

- Aturan member atau guest, masing masing anggota yang terdaftar atau tidak memiliki hak yang berbeda, tergantung dari kebijakan yang ditetapkan oleh pemilik forum.

\section{Channel}

Channel dalam bahasa Indonesia berarti saluran, channel mempunyai beberapa tayangan atau video yang terdapat di dalamnya. Seperti halnya pada channel stasiun TV yang mempunyai program acara sesuai dengan jenis salurannya. Salah satu kegunaan channel adalah untuk menggolongkan beberapa jenis tayangan akan ditampilkan. Sehingga dapat membantu para penonton untuk dapat mengakses setiap saluran dengan mudah sesuai dengan keinginan atau kebutuhan informasi dari penonton. Setiap informasi akan lebih efektif jika disajikan berdasarkan jenis atau kategorinya. Saluran atau channel yang berisi video dapat diolah dan dikategorikan [2].

\section{Facebook API}

Facebook API adalah platform untuk membangun aplikasi yang tersedia untuk para anggota jaringan sosial Facebook. API ini memungkinkan aplikasi untuk menggunakan hubungan sosial dan informasi profil untuk membuat aplikasi yang lebih terkoneksi, dan untuk mempublikasikan kegiatan pada news feed dan profil

Berita halaman Facebook, tunduk pada pengaturan privasi pengguna individu. Dengan API, pengguna dapat menambahkan konteks sosial untuk aplikasi dengan memanfaatkan data profil, teman, page, kelompok, foto, dan acara [3]. Ada berbagai macam Facebook API, yaitu Graph API, Public feed API, Keyword Insights API, Chat API dan lain- lain.

Facebook API calls dikelompokkan ke dalam delapan kategori tindakan, yang membantu pengembangan aplikasi. Facebook API calls meliputi:

- facebook.auth menyediakan pemeriksaan otentikasi dasar bagi pengguna Facebook.

- facebook.feed menyediakan metode untuk mengirim umpan berita Facebook.

- facebook.friends menyediakan metode untuk query Facebook untuk berbagai pemeriksaan pada teman pengguna.

- facebook.notifications menyediakan metode untuk mengirim pesan ke pengguna.

- facebook.profile memungkinkan untuk mengatur Facebook Markup Language dalam profil pengguna.

- facebook.users memberikan informasi tentang pengguna (seperti konten dari profil pengguna dan mengecek login).

- facebook.events menyediakan cara untuk mengakses peristiwa Facebook.

- facebook.groups menyediakan metode untuk mengakses informasi untuk kelompok Facebook.

- facebook.photos menyediakan metode untuk berinteraksi dengan foto Facebook.

Platform Facebook menyediakan banyak alat bantu untuk mengakses informasi, namun pengembang bertanggung jawab untuk menyediakan logika bisnis sendiri melalui beberapa bahasa lain [4]. Facebook memfasilitasi ini melalui libraries klien "resmi" untuk PHP dan Java yang menyediakan metode untuk mengakses aplikasi Facebook. Namun, tidak semua orang menggunakan Java dan PHP secara eksklusif. Untuk membantu programmer yang ingin mengembangkan aplikasi Facebook, libraries klien tersedia untuk bahasa-bahasa berikut: ActionScript, ASP.NET, ASP (VBScript), ColdFusion, C ++, C \#, D, Emacs Lisp, Lisp, Perl, PHP, Python, Ruby, VB NET, Windows Mobile.

\section{HASIL DAN PEMBAHASAN}

Internet kini menjadi kebutuhan bagi setiap orang. Internet juga digunakan sebagai sarana untuk melakukan pencarian informasi. Dalam bidang apapun internet sangatlah dibutuhkan dan mempunyai peran dalam kegunaannya. Pada penelitian kali ini akan menghubungkan kegunaan internet dalam bidang seni yaitu pada dunia tari. Banyak para pelaku seni tari ini sendiri yang mencari sumber inspirasi dan informasi melalui internet dalam bentuk artikel atau video. Untuk mendapatkan informasi yang efisien tentunya pelaku seni tersebut akan mencari tempat dimana bisa mendapatkan apa yang dia butuhkan, dalam hal tersebut yang dimaksud 
adalah sebuah website. Website tersebut harus mempunyai ruang lingkup yang spesifik agar pengguna dapat mengakses website tersebut secara efisien.

Setelah melihat permasalahan yang telah dianalisis, dibuatlah sebuah website dengan ruang lingkup yang spesifik yaitu seputar dunia tari. Website yang akan dibuat akan mencakup beberapa hal, antara lain adalah berisikan konten foto dan video serta artikel yang dapat didiskusikan dalam sebuah forum diskusi di dalam website tersebut. Untuk forum diskusi ini, dilakukan perbandingan dengan salah satu website forum yang bernama http://www.dance-forums.com/ yang mempunyai kesamaan ruang lingkup untuk dilakukan perbandingan dan sebagai referensi dalam penggunaan fitur yang terdapat didalamnya seperti pembuatan thread, memberikan komentar dalam setiap threadnya, dan melakukan pin thread dari sisi adminnya. Dengan tujuan agar setiap pengguna yang ingin mencari informasi seputar dunia tari dapat mendapatkan informasi yang efisien. Penelitian ini juga akan menggunakan Facebook API dalam pembuatan website, agar pengguna dapat melakukan registrasi atau pembagian informasi dengan media sosial Facebook lebih mudah karena Facebook termasuk media sosial yang mempunyai banyak pengguna. Dengan demikian dapat membantu para pengguna agar dapat mengakses dan melakukan pencarian informasi seputar dunia tari dengan lebih efisien dan efektif. Selain itu disediakan beberapa fitur yang nantinya dapat digunakan oleh pengguna. Hak akses pengguna pada website ini akan terbagi menjadi 3 hak akses, yaitu:

- Admin: Pengguna yang memiliki akses penuh pada sistem dan bertanggung jawab dan mengolah semua konten pada website.

- Member: Pengguna yang sudah terdaftar pada website.

- Guest: Pengguna yang mengakses website.

Masalah yang akan diselesaikan dalam penelitian ini adalah pembuatan sebuah website dengan mempunyai fiturfitur untuk mendukung efisiensi penggunaannya dan menggunakan Facebook API sebagai fitur tambahan yang berfungsi membantu pengguna untuk melakukan registrasi pada website dan saat melakukan sharing content. Dengan demikian, tujuan utama website ini dibuat untuk membantu pengguna website agar lebih efisien dalam mendapatkan informasi yang dibutuhkan.

\section{A. Desain Sistem}

Setelah dilakukan identifikasi kebutuhan sistem yang akan dikembangkan, maka dirancanglah website yang dapat menyajikan informasi secara efisien sesuai dengan kebutuhan pengguna. Untuk lebih jelasnya, maka dibuatlah Use Case Diagram, Activity Diagram, ERD (Entity Relationship Diagram), CDM (Conceptual Data Model), dan PDM (Physical Data Model).

\section{i. Use Case Diagram}

Use Case Diagram menjelaskan urutan kegiatan yang dilakukan oleh actor atau pelaku dan sistem untuk mencapai tujuan tertentu, menggambarkan fungsionalitas yang diharapkan dari sebuah sistem, serta mempresentasikan interaksi antar aktor atau pelaku dengan sistem. Pada use case diagram akan terlihat aktor yang menggunakan sistem dan kegiatan yang dapat dilakukan oleh aktor tersebut.

Use case diagram pada website menjelaskan proses sebuah sistem yang melibatkan lebih dari 1 aktor dalam kegiatannya. Pada website yang akan dirancang, terdapat tiga jenis aktor yaitu admin, member dan guest. Setiap jenis aktor tersebut memiliki use case yang berbeda-beda sesuai dengan kebutuhannya. Berikut adalah use case diagram untuk setiap jenis pengguna website:

\section{- Admin}

Seperti yang terlihat di Gambar 1, admin adalah pengguna yang mempunyai akses penuh terhadap sistem dan bertanggung jawab atas semua konten yang terdapat di dalam website serta mengawasi lalu lintas komunikasi yang terdapat pada website. Dengan mempunyai hak akses penuh terhadap sistem, admin juga mempunyai wewenang dalam memperlakukan setiap member yang terdapat pada sistem jika terdapat member yang tidak menjalankan atau melanggar aturan pada website.

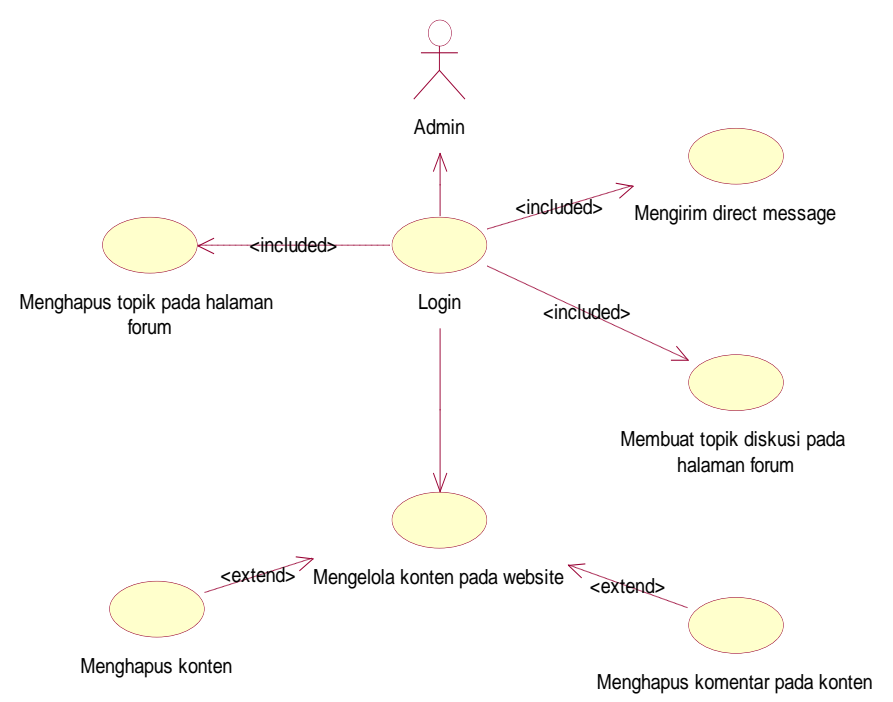

Gambar 1. Use Case Diagram Admin

\section{- Member}

Member adalah pengguna yang sudah melakukan registrasi pada website. Member dapat membuat sebuah topik diskusi pada halaman forum dan dapat mengunggah konten video pada halaman channel. Berikut di Gambar 2 adalah use case diagram yang dimiliki oleh member. 


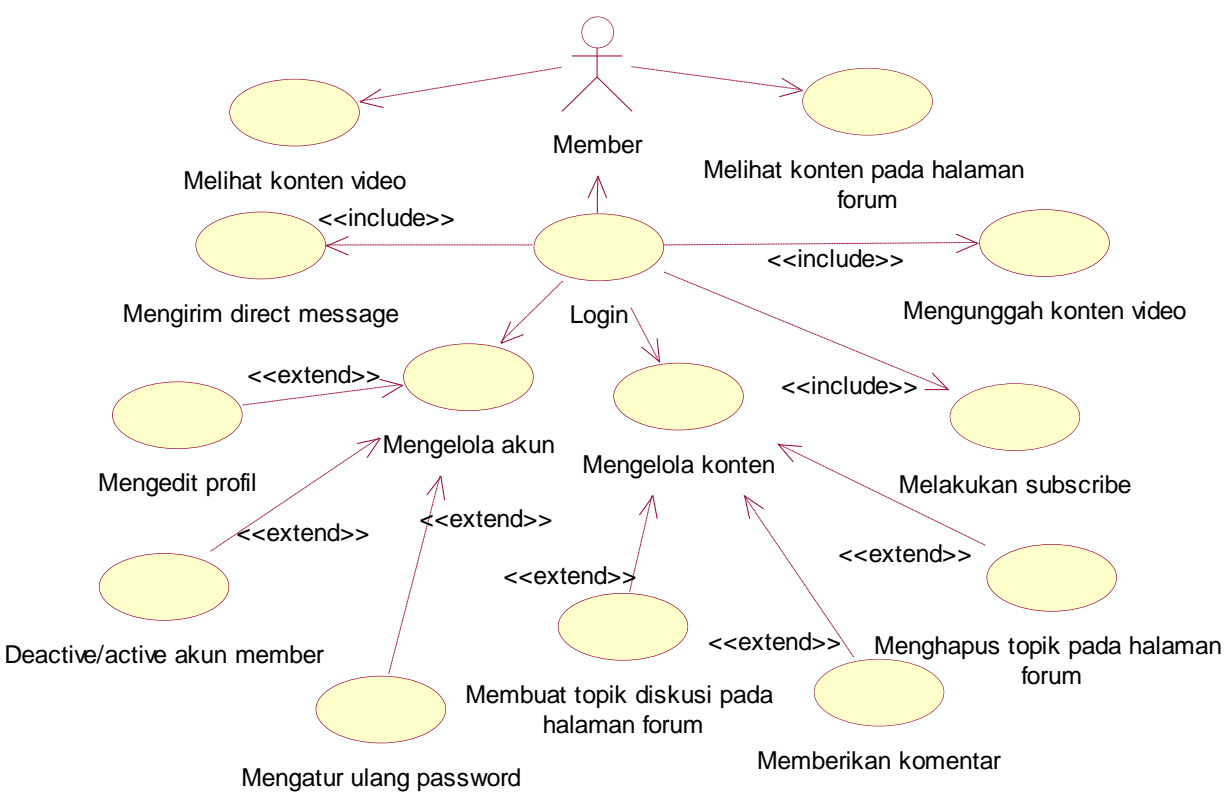

Gambar 2. Use Case Diagram Member

\section{- Guest}

Guest adalah pengguna yang belum melakukan registrasi. Guest memiliki fasilitas yang terbatas pada website. Guest hanya dapat mengakses website tetapi tidak bisa memberikan respon atau perintah apapun terhadap semua konten yang terdapat di dalam sistem. Guest dapat memberikan respon dan perintah pada setiap konten yang terdapat pada website ketika status guest sudah terdaftar menjadi member yang sudah terverifikasi. Berikut adalah use case diagram yang dimiliki oleh guest.

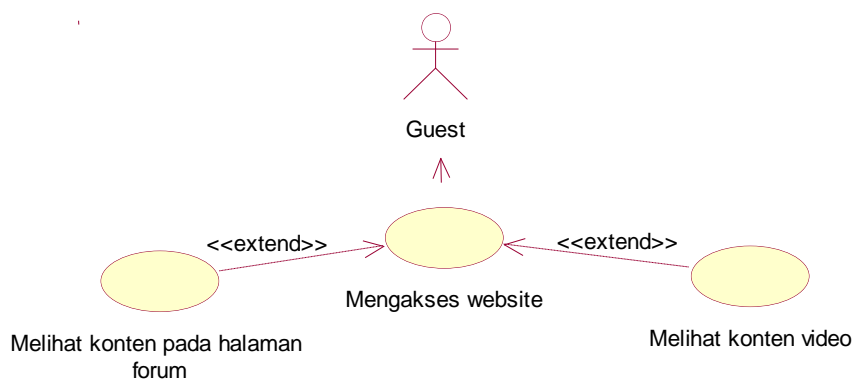

Gambar 3. Use Case Diagram Guest

\section{ii. Activity Diagram}

Activity diagram menggambarkan rangkaian aliran dari aktivitas, digunakan untuk mendeskripsikan aktivitas yang terbentuk dalam suatu operasi. Activity diagram dibentuk berdasarkan use case diagram yang telah dibuat sebelumnya. Berikut ini adalah beberapa activity diagram dari sistem yang dibuat.

- Activity Diagram Melakukan Login Oleh Admin Adalah aktivitas yang dilakukan oleh admin untuk masuk ke dalam sistem. Activity diagram login digambarkan sebagai berikut:

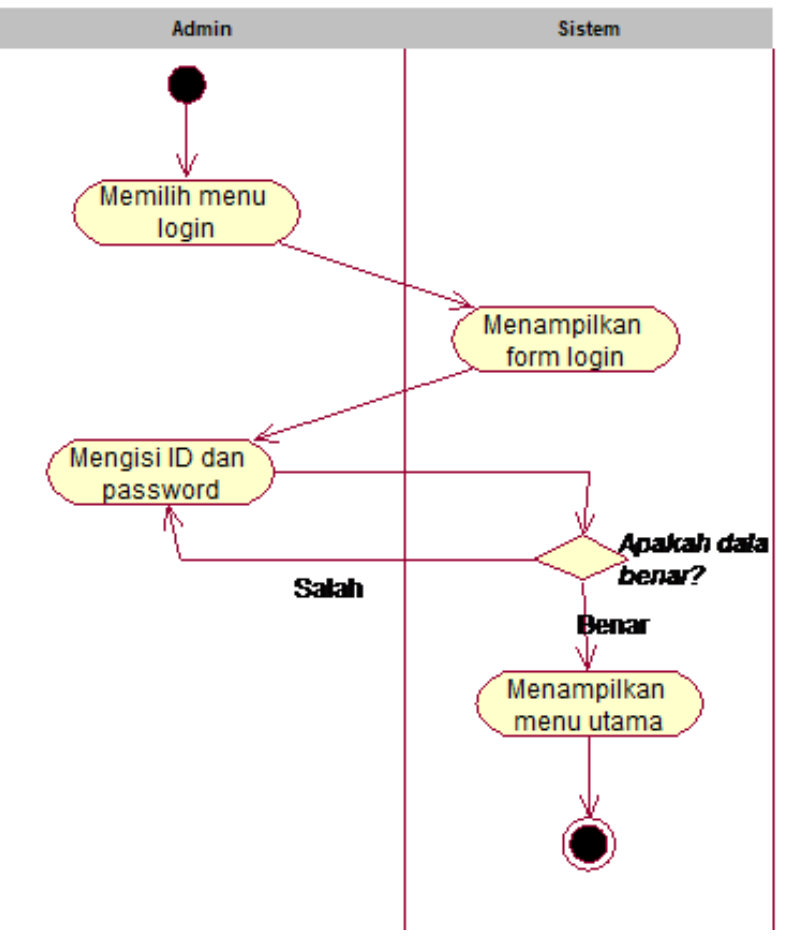

Gambar 4. Activity Diagram Melakukan Login

- Activity Diagram Login dengan Facebook API Adalah aktivitas yang dilakukan oleh member untuk masuk ke dalam sistem. Activity diagram login menggunakan Facebook API sebagai berikut: 


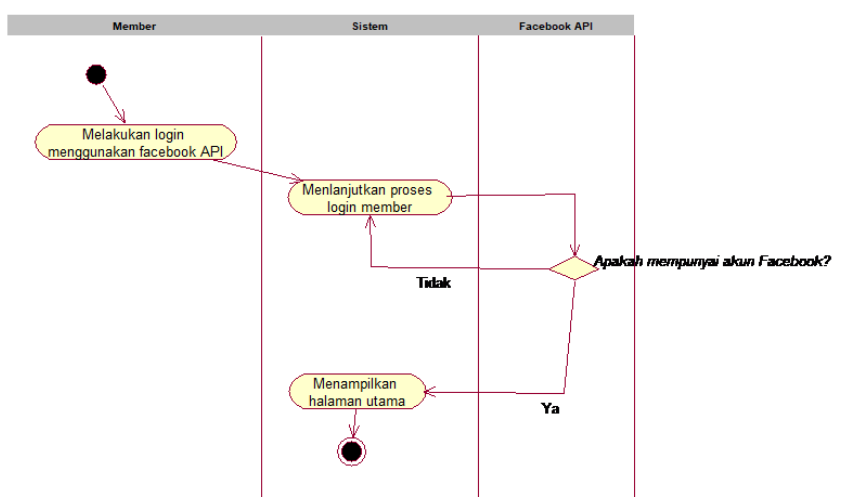

Gambar 5. Activity Diagram Login Facebook API

- Activity Diagram Mengunggah Konten

Activity diagram mengunggah konten adalah aktivitas yang dilakukan oleh member untuk mengunggah konten foto atau video. Activity diagram mengunggah konten foto atau video sebagai berikut:

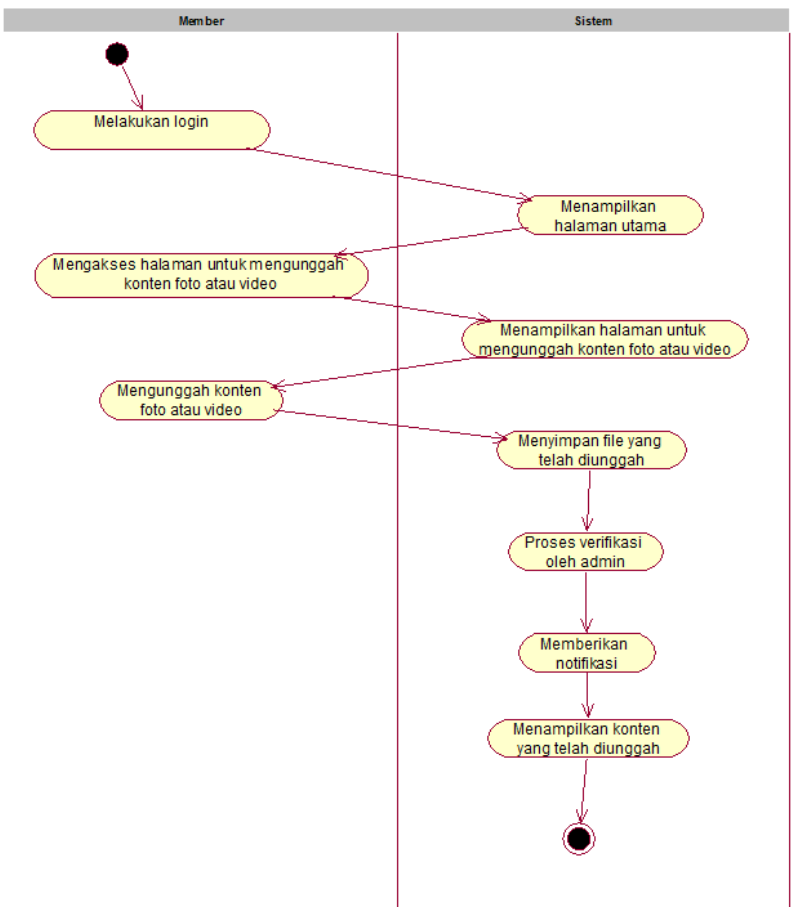

Gambar 6. Activity Diagram Mengunggah Konten

\section{iii. Sequence Diagram}

Sequence diagram merupakan gambaran interaksi antar masing-msaing obyek pada setiap use case dalam urutan waktu. Interaksi ini berupa pengiriman serangkaian data antar obyek-obyek yang saling berinteraksi. Pada sequence diagram yang dibuat, dibagi menjadi tiga berdasarkan aktor yang terlibat di dalam sistem dan dari ketiga aktor tersebut akan dibagi lagi berdasarkan use case yang terdapat pada masing-masing aktor.

- Sequence Diagram Menghapus Topik

Sequence diagram menghapus topik dalam halaman forum menunjukkan proses yang dilakukan oleh admin untuk menghapus topik dalam halaman forum. Berikut ini adalah sequence diagram menghapus topik dalam halaman forum.

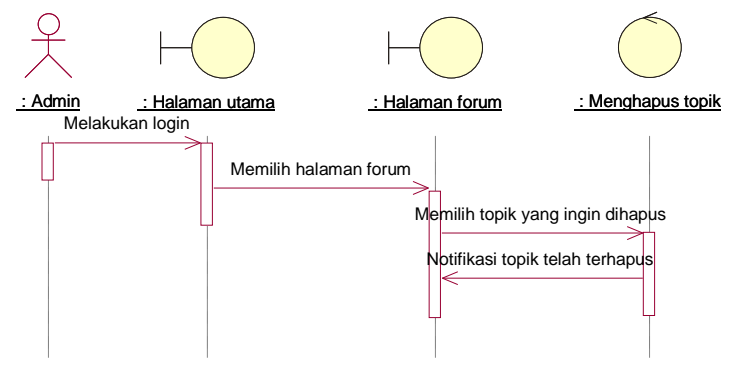

Gambar 7. Sequence Diagram Menghapus Topik

- Sequence Diagram Memberikan Komentar

Sequence diagram mengomentari konten foto atau video menunjukkan proses yang dilakukan oleh member untuk mengomentari konten foto atau video. Berikut ini adalah sequence diagram mengomentari konten foto atau video.

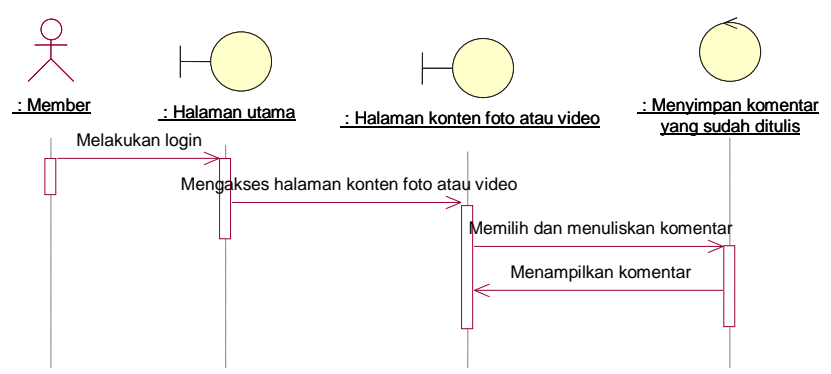

Gambar 8. Sequence Diagram Memberikan Komentar

- Sequence Diagram Deaktivasi Akun Member

Sequence diagram deaktivasi akun member menunjukkan proses yang dilakukan member untuk mengubah status akunnya menjadi non aktif. Berikut ini adalah sequence diagram deaktivasi akun member:

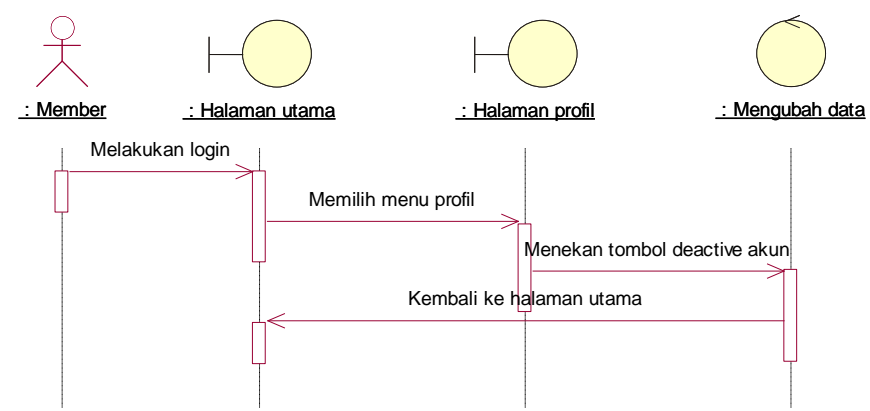

Gambar 9. Sequence Diagram Deactive Akun Member

iv. Entity Relationship Diagram

Entity Relationship Diagram merupakan metode yang sering dipakai untuk membantu menganalisis pembuatan basis data suatu sistem, sehingga dengan adanya Entity Relationship Diagram hubungan antar tabel dapat diidentifikasi dengan jelas. Dengan ERD (Entity Relationship Diagram) pembuatan perencanaan website dapat dideskripsikan. Selain itu juga ERD membantu mempermudah penulis dalam membuat website. Dengan 
entitas dan relasi yang sudah dirancang, penulis dapat memberikan penjelasan yang lengkap dari Entity Relationship Diagram. Gambar Entity Relationship Diagram website ini dapat dilihat pada gambar 10 .

\section{v. Conceptual Data Model (CDM)}

Conceptual Data Model adalah model yang digunakan untuk memodelkan struktur dari keseluruhan aplikasi basis data secara detil dan logis. Conceptual Data Model dalam penerapannya dapat disamakan dengan Entity Relationship Diagram yang fungsinya memang sama yaitu memodelkan struktur dari basis data. Gambar 11 adalah Conceptual Data Model dari sistem yang akan dibuat.

Berdasarkan gambar 11 dapat diketahui tentang entitas yang akan digunakan untuk kebutuhan sistem. Terdapat 7 entitas yaitu entitas data user, data content, data forum, data subscriber, data direct message, data content comment dan data forum comment. Pada Conceptual Data Model diatas terdapat satu derajat relasi many-to-many pada saat pembuatan Entity Diagram Realtionship pada entitas user terhadap subscriber sehingga menghasilkan entitas baru yaitu subscription. Untuk entitas yang lain mempunyai derajat relasi one-to-many terhadap user.

Pada Conceptual Data Model belum terdapat foreign key yang menghubungkan antara relasi satu dengan lainnya. Foreign key tersebut nantinya akan muncul pada saat Conceptual Data Model digeneralisasi menjadi Physical Data Model.

\section{vi. Physical Data Model (PDM)}

Physical Data model adalah sebuah gambaran rancangan secara detail dari database dalam bentuk fisik yang merupakan hasil generalisasi dari Conceptual Data Model sebelumnya. Gambar 12 adalah Physical Data Model dari sistem yang akan dibuat.

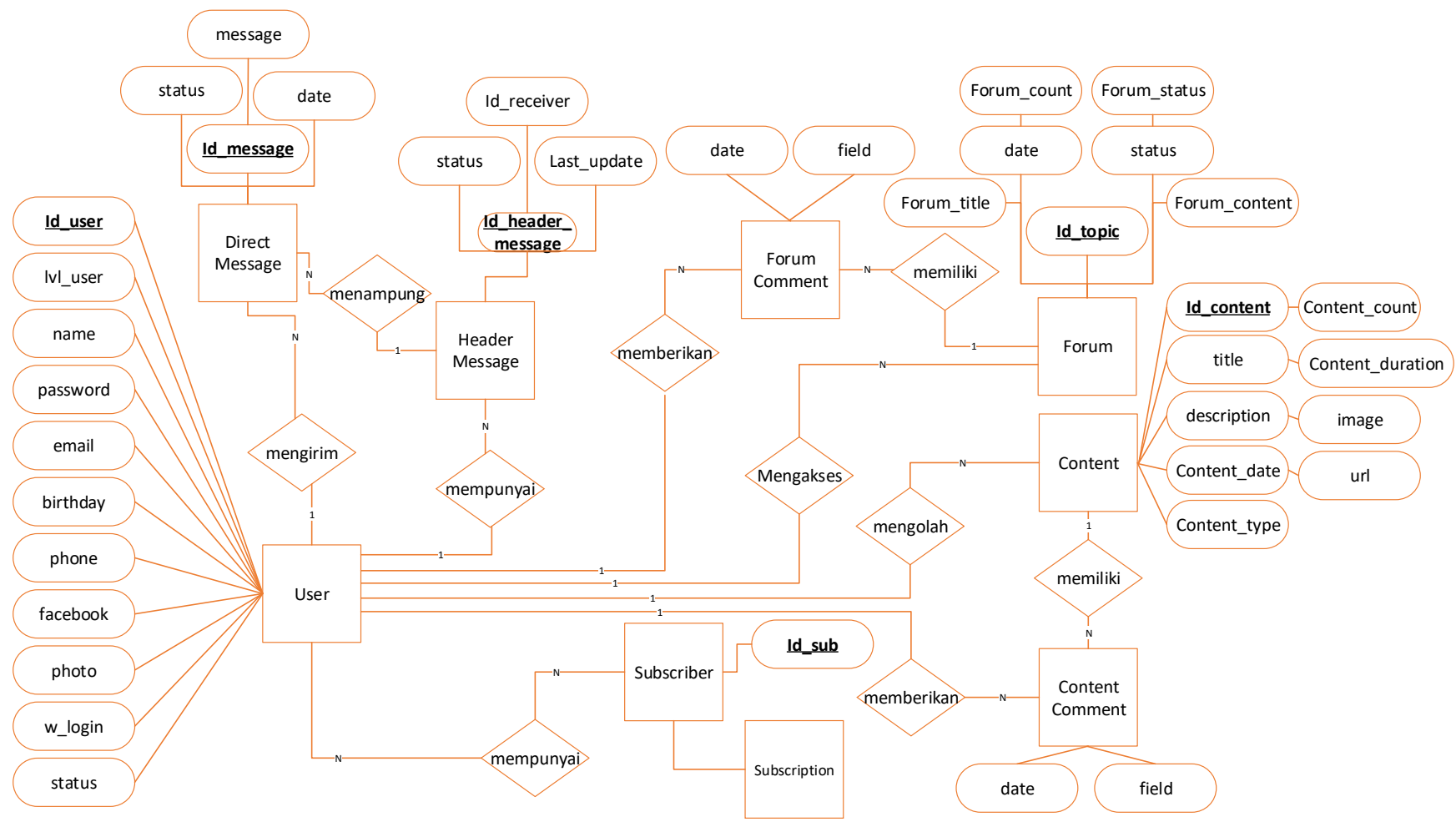

Gambar 10. Entity Relationship Diagram 


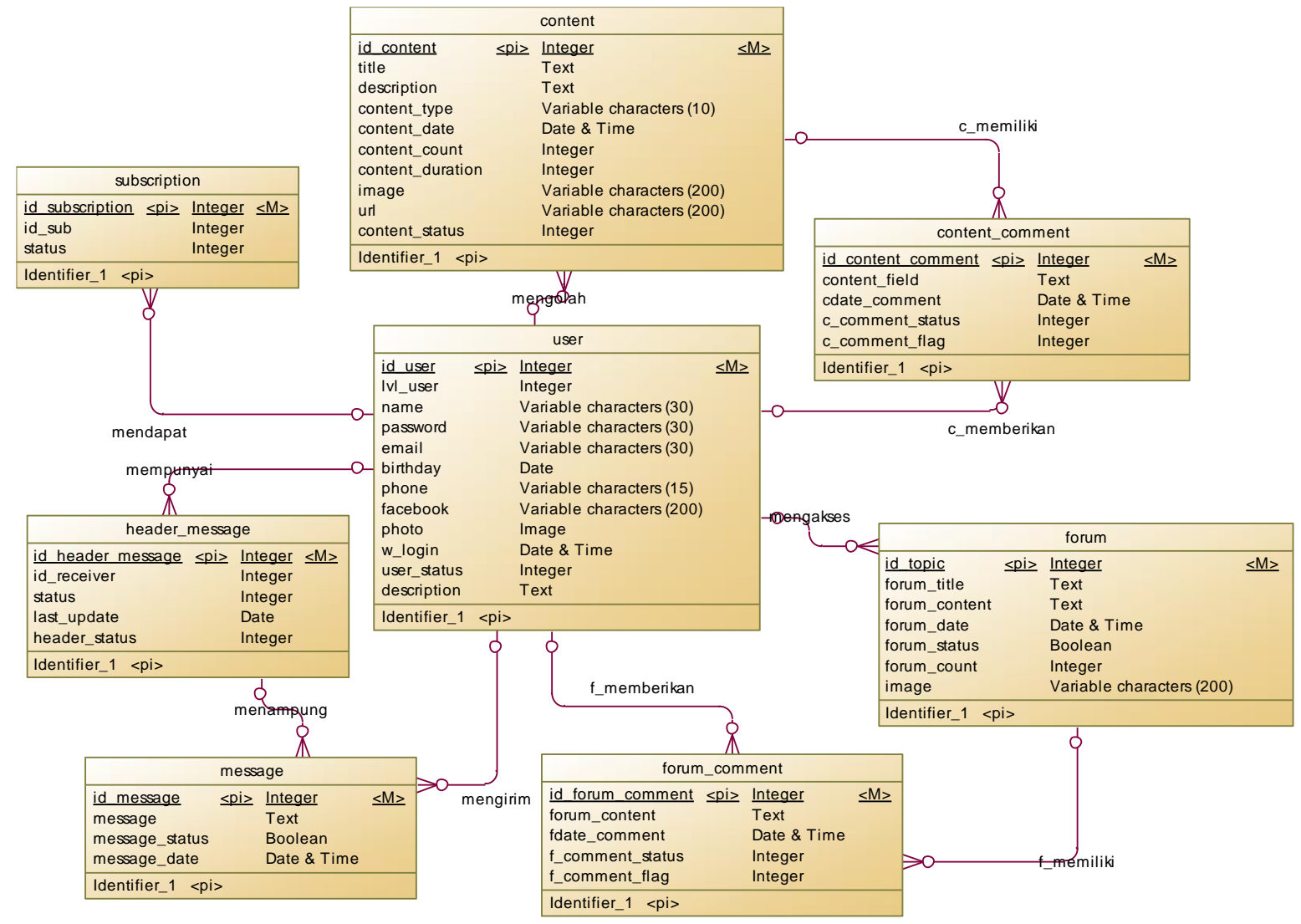

Gambar 11. Conceptual Data Model Website Media Sosial

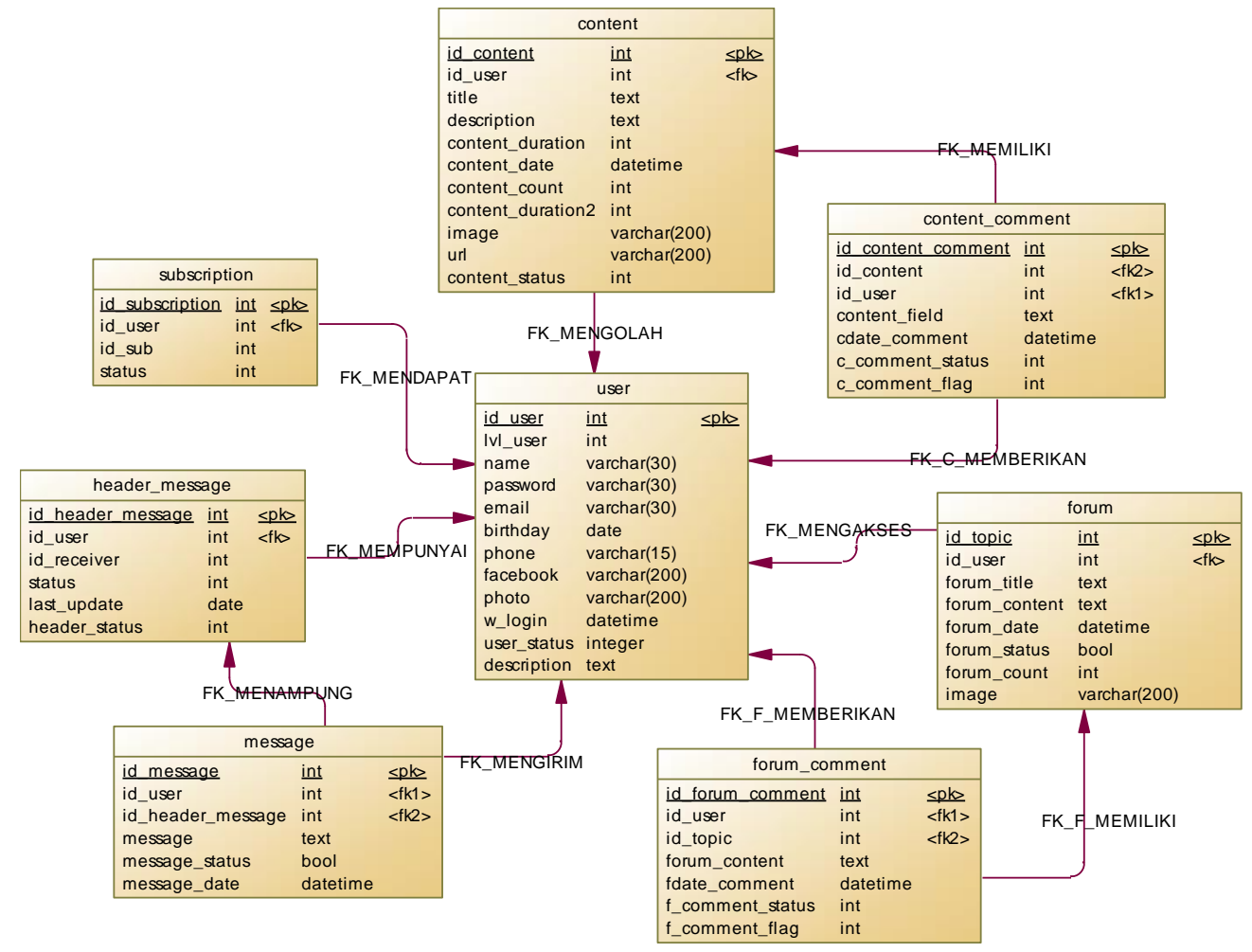

Gambar 12. Physical Data Model Website Media Sosial 


\section{B. Desain Arsitektural}

Desain arsitektural memaparkan tentang apa yang digunakan dalam membangun sistem. Selain itu, pembangunan sebuah sistem membutuhkan pertimbangan desain yang akan diterapkan dalam sebuah sistem.

Dalam pembuatannya, suatu website akan membutuhkan database yang akan digunakan untuk menyimpan semua data yang berada pada website. website ini, dalam pembuatannya menggunakan database MySQL 5.1.41. selain itu, untuk mengakses website, pengguna harus memiliki koneksi internet sehingga dapat menghubungkan mereka dengan web server. Gambaran desain arsitektural dari website yang akan dibuat adalah seperti yang tertera pada gambar 13 .

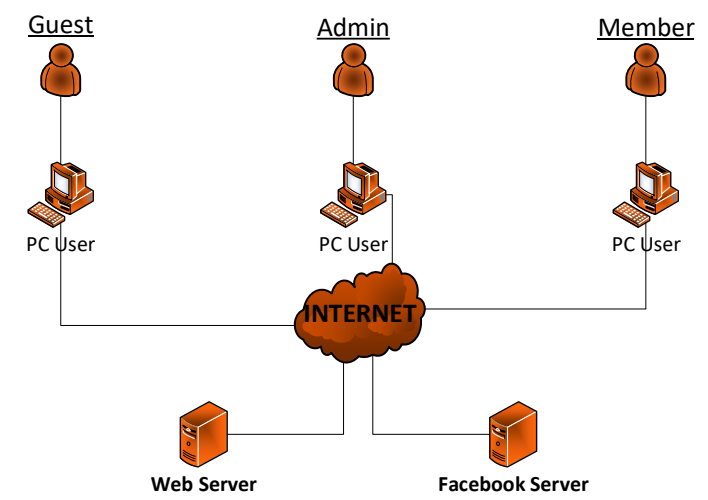

Gambar 13. Desain Arsitektural Website Media Sosial

Pada gambar 13 dijelaskan desain arsitektural yang dimiliki oleh website yang akan dibuat. Dari desain arsitektural tersebut dijelaskan bahwa pengguna harus terhubung dengan internet dengan menggunakan PC untuk dapat mengakses web server. Website yang akan dibuat nantinya juga akan memanfaatkan Facebook API. Website yang akan di buat dapat di akses oleh 3 jenis pengguna, yaitu admin, member, dan guest.

\section{Desain Prototype}

Berdasarkan ketiga desain prototype yang sudah dibuat akan dipilih desain yang sudah didapat dari hasil kuesioner yang sudah dibuat dengan menggunakan Google Docs sebagai media survei secara online dengan melampirkan 16 pertanyaan sebagai tolak ukur perancangan dan pemilihan desain yang dilakukan oleh penulis. Penulis membagikan kepada 76 respoden untuk mendapatkan hasil yang sesuai.

Berikut adalah desain yang banyak dipilih:

1. Desain Halaman Utama

Halaman utama akan muncul ketika pertama kali saat pengguna mengakses website ini. Pada halaman utama ini, pengguna dapat mengakses semua konten yang terdapat pada sistem website tetapi tidak bisa melakukan aktifitas yang berhubungan dengan konten seperti memberikan komentar atau membagikan konten pada media sosial Facebook kecuali pengguna tersebut sudah melakukan login dan sudah terdaftar pada sistem website.

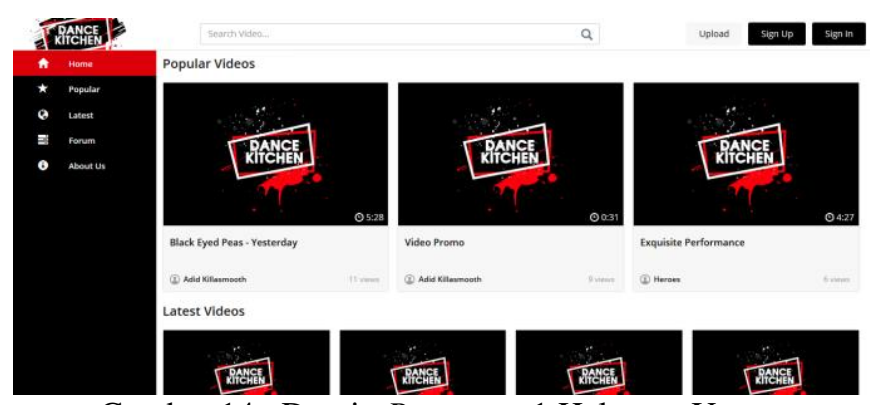

Gambar 14. Desain Prototype 1 Halaman Utama

Halaman utama akan menampilkan konten-konten yang terdapat pada sistem dengan tampilan pilihan menu yang terdapat pada sebelah kiri. Halaman utama ini akan mempunyai lima sub halaman dan bukan termasuk halaman Upload, Sign up, dan Sign in.

2. Desain Halaman Channel

Halaman channel merupakan halaman yang dimiliki oleh member yang sudah terdaftar pada sistem, dimana halaman tersebut menampilkan konten foto dan video yang sudah diunggah oleh member pada sistem serta berisikan profil dari member tersebut. Halaman ini juga mempunyai deskripsi dari channel dan juga terdapat jumlah subscriber.

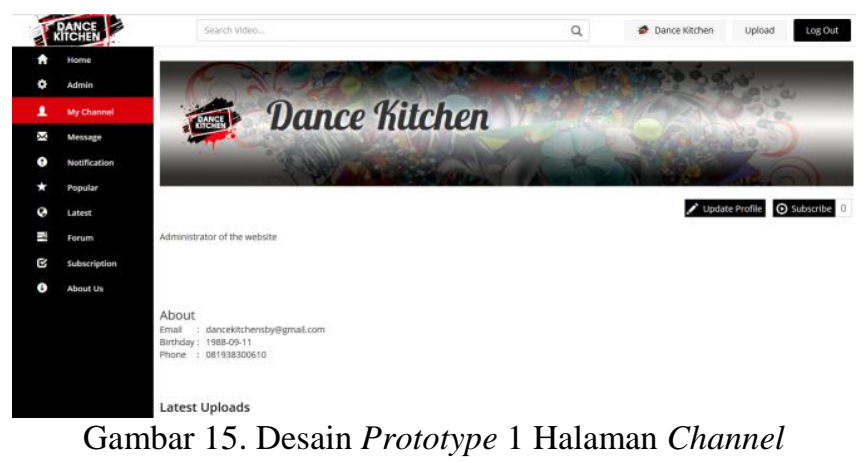

Halaman ini mempunyai tampilan yang sama seperti halaman utama dengan pilihan sub menu yang terdapat di sebelah kiri website. Halaman ini juga menampilkan siapa saja yang sudah menjadi subscriptions dari member tersebut.

3. Desain Halaman Forum

Halaman forum adalah halaman yang bisa diakses oleh setiap pengguna tetapi hanya member dan admin saja yang dapat mengelola halaman ini, sedangkan guest hanya bisa mengakses dan tidak dapat memberikan komentar pada halaman ini. Halaman ini berisikan forum diskusi yang mempunyai topik tertentu dan sudah dibuat oleh admin atau member yang terdaftar pada sistem. 


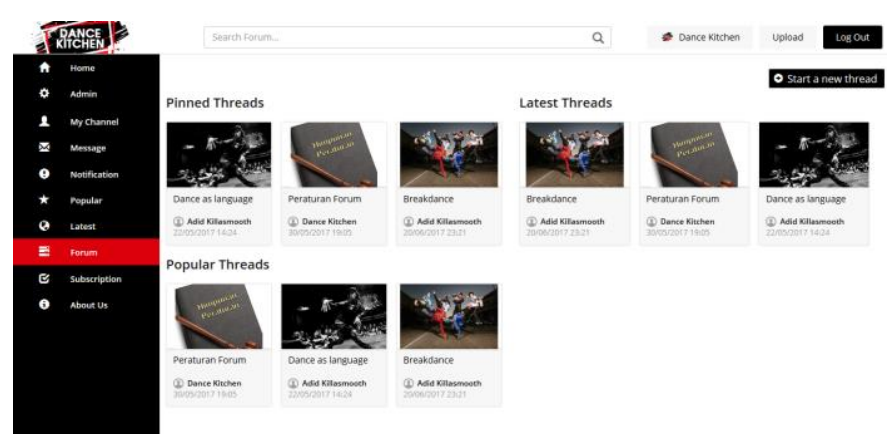

Gambar 16. Desain Prototype 1 Halaman Forum

Halaman forum ini mempunyai tampilan yang berbeda dari tampilan halaman forum pada umumnya. Halaman forum ini mempunyai tampilan thumbnail pada topik diskusinya sehingga lebih menarik untuk diakses, tetapi thumbnail tersebut bisa diatur secara default agar mempermudah member untuk membuat sebuat topik diskusi baru.

\section{Spesifikasi dan Kemampuan Sistem}

Pada bagian ini akan dijelaskan hasil implementasi sistem pada bagian sebelumnya berupa spesifikasi dan kemampuan yang dimiliki dari Website Media Sosial Untuk Komunitas Dunia Tari yang telah dibuat. Dalam penggunaan Sistem Website Media Sosial ini, penulis menggunakan spesifikasi sebagai berikut :

- Spesifikasi minimum pada perangkat yang di butuhkan oleh server:

* Perangkat Keras :

- Intel Xeon Scalable

- RAM: 2 GB

- Space: $1 \mathrm{~GB}$

* Perangkat Lunak

- Sistem operasi : Windows 7

- Apache versi 2.2.

- PHP versi 5.5.

- MySQL versi 5.1.61.

- Perangkat dan aplikasi yang di butuhkan oleh user:

* PC Desktop.

* Web Browser Google Chrome® versi 55.0.2883.87 dan Mozilla Firefox ${ }^{\circledR}$ versi 51.0.1 untuk PC Desktop.

* Kecepatan koneksi internet minimal $128 \mathrm{Kbps}$.

E. Kemampuan Sistem

Sistem Website Media Sosial ini memiliki beberapa kemampuan sistem antara lain :

1. Admin mempunyai kemampuan untuk mengolah setiap konten yang terdapat pada sistem.

2. Admin dapat mengirimkan direct message kepada semua member yang terdaftar.

3. Admin dapat melakukan pin thread pada topik yang terdapat di halaman forum.

4. Admin dapat memblokir atau menonaktifkan member.

5. User dapat melakukan sign up atau login menggunakan Facebook.
6. Member dapat membagikan konten melalui media sosial Facebook.

7. Member dapat mengunggah video dan membuat topik diskusi pada website.

8. Member dapat mengirimkan direct message kepada member yang lain.

9. Member dapat memberikan komentar pada konten yang terdapat pada website.

10. Member dapat melakukan subscribe terhadap member yang lain.

\section{IV.HASIL DAN PEMBAHASAN}

Pada bagian ini akan dijelaskan mengenai proses uji coba terhadap website Media Sosial Untuk Komunitas Dunia Tari yang telah dibuat. Uji coba akan dilakukan menggunakan black box testing untuk dilakukan pengujian terhadap fungsionalitas fitur yang terdapat pada website dengan menggunakan beberapa skenario.

\section{A. Black Box Testing}

Testing yang dilakukan pada website akan berfokus pada setiap proses yang mempunyai input dari user dan output yang akan dihasilkan oleh sistem. Setiap skenario yang dilakukan oleh user harus mempunyai hasil yang sama dengan output dari sistem.

Pengujian akan dilakukan dengan cara mencoba beberapa skenario yang terdapat pada website dan setiap fitur apakah sesuai dengan fungsinya. Penulis mencoba website ini kepada user dan admin agar mengetahui apakah semua menu dan fitur-fitur berjalan dengan baik.

\section{i. Pengujian Pada Sisi Admin}

Pengujian pada sistem dari sisi admin akan dilakukan pengecekan terhadap beberapa skenario yang tidak dapat dilakukan oleh user lain. Pengecekan ini akan melibatkan user dan konten yang terdapat pada sistem website. Penulis akan menuliskan 3 skenario yang akan dilakukan uji coba dari sisi admin. Berikut adalah contoh skenarionya:

Tabel 1. Skenario Memblokir Akun Member

\begin{tabular}{llll}
\hline Admin & Proses Sistem & $\begin{array}{c}\text { Hasil } \\
\text { Proses }\end{array}$ & $\begin{array}{c}\text { Kondisi } \\
\text { Skenario }\end{array}$ \\
\hline \multirow{4}{*}{$\begin{array}{l}\text { Melakukan } \\
\text { perubahan status }\end{array}$} & $\begin{array}{l}\text { Notifikasi } \\
\text { pada }\end{array}$ & Sesuai \\
pada member & halaman & \\
Menekan & yang diblokir & website & \\
icon & oleh admin & & \\
trash & Mengirimkan & Email & Sesuai \\
& email kepada & dikirim & \\
& member yang & pada & \\
& diblokir & member & \\
& & yang & \\
& & diblokir & \\
\hline
\end{tabular}

Pada tabel 1 dijelaskan bahwa sistem akan melakukan proses setelah admin menekan icon trash dengan mengubah 
status pada member untuk diblokir dari sistem dan diberikan notifikasi kepada email yang didaftarkan oleh member. Member akan mendapatkan email dari sistem dan email yang sudah diblokir tidak dapat digunakan lagi pada sistem website. Kondisi skenario akan sesuai jika semua proses berjalan sesuai prosedur.

\begin{tabular}{|c|c|c|c|c|c|c|c|}
\hline 1 & Adid Kllasmooth & alhadidammash@gmall.com & 11/11/1988 & 08113110988 & 21/06/2017 11:30 & Active & it \\
\hline 2 & Adid Killasmooth & killasmooth88@yahoo.com & $01 / 01 / 1970$ & & 02/08/2017 13:18 & Active & \# \\
\hline 4 & Al Hadid Ammash & alhadidammasheyahoo.com & 01/01/1970 & 081938300610 & 03/08/2017 13:44 & Active & in \\
\hline 5 & Rada Pavita & radapavitas@yahoo.com & 05/12/1999 & 082232433999 & 20/06/2017 23:12 & Active & it \\
\hline 3 & vanessa jocelyn & vanjoccc@gmail.com & $05 / 01 / 1996$ & 082231239226 & 20/06/2017 23:03 & Active & if \\
\hline
\end{tabular}

Gambar17. Halaman Registered User

Pada gambar 17 ditampilkan setiap member yang terdaftar dalam sistem. Pada setiap member terdapat status active, yang menandakan member tersebut terdaftar dalam sistem dan aktif. Status akan berubah jika admin menekan icon trash pada member yang ingin diblokir.

\section{ii. Pengujian Sistem Sign Up Oleh User}

Pengujian pada sistem sign up akan dilakukan pengecekan terhadap setiap input yang diberikan oleh user pada waktu mendaftar. User harus menggunakan email yang aktif supaya dapat mengakses link verifikasi yang dikirimkan oleh sistem kecuali user yang mendaftar menggunakan akun Facebook.

Tabel 2. Skenario Sign Up Menggunakan Email

\begin{tabular}{llll}
\hline $\begin{array}{c}\text { Data } \\
\text { Masukan }\end{array}$ & \multicolumn{1}{c}{$\begin{array}{c}\text { Proses } \\
\text { Sistem }\end{array}$} & $\begin{array}{c}\text { Hasil } \\
\text { Proses }\end{array}$ & $\begin{array}{c}\text { Kondisi } \\
\text { Skenario }\end{array}$ \\
\hline $\begin{array}{l}\text { Email } \\
\text { (terdapat }\end{array}$ & $\begin{array}{l}\text { Melakukan } \\
\text { pengecekan } \\
\text { a dan .) }\end{array}$ & $\begin{array}{l}\text { Notifikasi } \\
\text { pada }\end{array}$ & Sesuai \\
& $\begin{array}{l}\text { sesuai dengan } \\
\text { format email. }\end{array}$ & $\begin{array}{l}\text { kolom } \\
\text { email }\end{array}$ & \\
\hline $\begin{array}{l}\text { Password } \\
\text { (min. 6 }\end{array}$ & Melakukan & Notifikasi & Sesuai \\
karakter) & apakah input & kolom & \\
& sesuai dengan & password & \\
& format & & \\
& susunan & & \\
password. & & \\
\hline Mobile & Melakukan & Notifikasi & Sesuai \\
Number & pengecekan & pada & \\
& input berupa & kolom & \\
& angka & number & \\
\hline
\end{tabular}

Pada tabel 2 dijelaskan bahwa setiap data yang dimasukkan akan diproses oleh sistem dan setelah dilakukan pengecekan, sistem akan memberikan hasil proses tersebut sebagai output dengan memberikan notifikasi pada halaman website. Sistem akan megirimkan link verifikasi pada email yang sudah didaftarkan. Status kondisi adalah tolak ukur apakah skenario yang dilakukan sesuai dengan sistem yang dibuat. Jika input yang dilakukan oleh user sesuai dengan output yang dihasilkan oleh sistem, maka kondisi skenario tersebut sesuai.

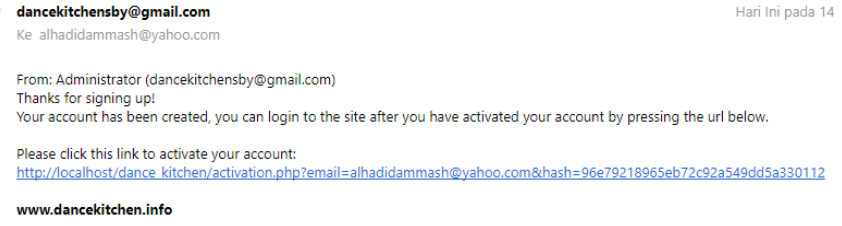

Gambar 18. Notifikasi Email Activation Link Dari Sistem

Pada gambar 18 dijelaskan bahwa sistem akan mengirimkan notifikasi melalui email kepada user yang berhasil melakukan registrasi. Sistem memberikan activation link untuk diakses agar user tersebut terdaftar sebagai member yang sudah diverifikasi oleh sistem.

\section{iii. Pengujian Login Menggunakan Facebook}

Pengujian pada sistem login akan dilakukan pengecekan terhadap user yang sudah terdaftar atau belum. User akan mencoba login dengan menggunakan akun Facebook

Tabel 3. Skenario Login Menggunakan Facebook

\begin{tabular}{|c|c|c|c|}
\hline $\begin{array}{c}\text { Data } \\
\text { Masukan }\end{array}$ & Proses Sistem & $\begin{array}{c}\text { Hasil } \\
\text { Proses }\end{array}$ & $\begin{array}{c}\text { Kondisi } \\
\text { Skenario }\end{array}$ \\
\hline $\begin{array}{l}\text { Tautan } \\
\text { Facebook }\end{array}$ & $\begin{array}{l}\text { Menghubungkan } \\
\text { dengan akun } \\
\text { Facebook }\end{array}$ & $\begin{array}{l}\text { Membuka } \\
\text { halaman } \\
\text { Facebook }\end{array}$ & Sesuai \\
\hline \multirow[t]{2}{*}{ Email } & \begin{tabular}{l}
\multicolumn{2}{l}{ Melakukan } \\
pengecekan \\
apakah input \\
sesuai dengan \\
format susunan \\
email.
\end{tabular} & $\begin{array}{l}\text { Notifikasi } \\
\text { pada } \\
\text { halaman } \\
\text { website } \\
\text { Facebook }\end{array}$ & Sesuai \\
\hline & $\begin{array}{l}\text { Melakukan } \\
\text { pengecekan } \\
\text { terhadap basis } \\
\text { data Facebook }\end{array}$ & $\begin{array}{l}\text { Notifikasi } \\
\text { pada } \\
\text { halaman } \\
\text { website } \\
\text { Facebook }\end{array}$ & Sesuai \\
\hline \multirow[t]{2}{*}{ Password } & $\begin{array}{l}\text { Melakukan } \\
\text { pengecekan } \\
\text { terhadap basis } \\
\text { data Facebook }\end{array}$ & $\begin{array}{l}\text { Notifikasi } \\
\text { pada } \\
\text { halaman } \\
\text { website }\end{array}$ & Sesuai \\
\hline & $\begin{array}{l}\text { Melakukan } \\
\text { pengecekan } \\
\text { apakah input } \\
\text { sesuai dengan } \\
\text { format susunan } \\
\text { password. }\end{array}$ & $\begin{array}{l}\text { Notifikasi } \\
\text { pada } \\
\text { halaman } \\
\text { website } \\
\text { Facebook }\end{array}$ & Sesuai \\
\hline
\end{tabular}

Pada tabel 3 dijelaskan bahwa sistem akan menghubungkan proses login ke halaman Facebook untuk dapat login menggunakan akun Facebook. Setelah proses login di halaman Facebook sudah diverifikasi, maka sistem dari Facebook akan mengembalikan ke halaman utama website dengan status sudah login.

Status kondisi adalah tolak ukur apakah skenario yang dilakukan sesuai dengan sistem yang dibuat. Jika input yang dilakukan oleh user sesuai dengan output yang dihasilkan oleh sistem, maka kondisi skenario tersebut sesuai. 


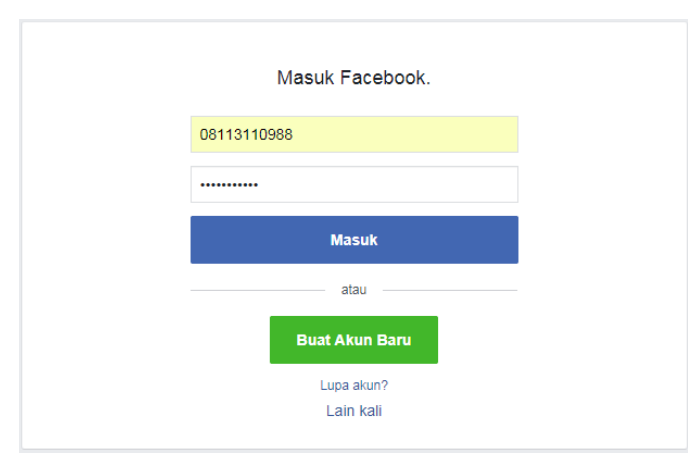

Gambar 19. Form Login Halaman Facebook

Pada gambar 19 dijelaskan pada form login Facebook akan melakukan pengecekan data yang dimasukkan oleh user terhadap basis data Facebook untuk diverifikasi. Basis data pada Facebook tersebut nantinya akan diintegrasikan oleh basis data pada website yang dibuat oleh penulis. Setelah login dengan Facebook berhasil, maka halaman akan kembali ke halaman utama website dengan status sudah login.

\section{iv. Pengujian Upload Konten Oleh User}

Pengujian pada saat melakukan upload konten akan dilakukan pengecekan terhadap konten yang akan diunggah oleh user berdasarkan besar file yang akan diunggah dan pengisian form yang terdapat pada saat upload. Pengujian ini dibagi menjadi 2 skenario, yaitu skenario pada saat upload video dan skenario pada saat pembuatan topik baru pada halaman forum. Berikut adalah contoh skenarionya:

Tabel 4. Skenario Upload Konten Video

\begin{tabular}{llll}
\hline $\begin{array}{c}\text { Data } \\
\text { Masukan }\end{array}$ & \multicolumn{1}{c}{$\begin{array}{c}\text { Proses } \\
\text { Sistem }\end{array}$} & $\begin{array}{c}\text { Hasil } \\
\text { Proses }\end{array}$ & $\begin{array}{c}\text { Kondisi } \\
\text { Skenario }\end{array}$ \\
\hline Title & $\begin{array}{l}\text { Melakukan } \\
\text { pengecekan } \\
\text { terhadap } \\
\text { kolom title }\end{array}$ & $\begin{array}{l}\text { Notifikasi } \\
\text { pada } \\
\text { kolom }\end{array}$ & Sesuai \\
& title & \\
\hline Thumbnail & Melakukan & Notifikasi & Sesuai \\
(max.2MB) & pengecekan & pada & \\
& pada foto & halaman & \\
& yang & website & \\
& diunggah & & \\
\hline Video & Melakukan & Notifikasi & Sesuai \\
pengecekan & pada & \\
600MB) & pada video & halaman & \\
& yang & website & \\
& diunggah & & \\
\hline Description & Melakukan & Notifikasi & Sesuai \\
& pengecekan & pada & \\
& terhadap & kolom & \\
& kolom & & \\
& description & & \\
\hline
\end{tabular}

Pada tabel 4. dijelaskan bahwa setiap kolom yang terdapat pada halaman upload harus diisi kecuali pada thumbnail untuk video yang akan diunggah. Setiap kolom akan dilakukan pengecekan dan sistem akan memberikan notifikasi pada kolom yang masih kosong. Status kondisi adalah tolak ukur apakah skenario yang dilakukan sesuai dengan sistem yang dibuat.

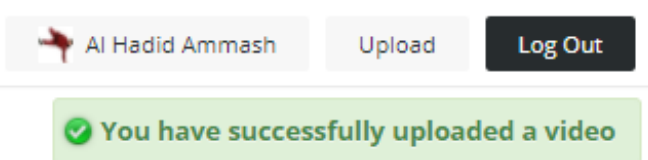

Gambar 20. Notifikasi Upload Video Berhasil

Pada gambar 20 dijelaskan bahwa video yang berhasil diunggah ke dalam sistem akan dilakukan pengecekan. Jika semua sesuai dengan sistem maka proses dilanjutkan oleh sistem untuk diberikan output berupa notifikasi bahwa video sudah berhasil diunggah dan video disimpan pada basis data.

\section{KESIMPULAN}

Pada sub bab ini akan disimpulkan beberapa kesimpulan yang dapat diambil dari proses pembuatan Website Media Sosial Untuk Komunitas Dunia Tari. Kesimpulan yang dapat diambil antara lain :

1. Website media sosial ini akan menjadi wadah bagi komunitas tari dan dapat membantu untuk berkembangnya komunitas dunia tari melalui setiap konten-konten yang bersifat global sehingga informasi yang didapatkan mempunyai ruang lingkup yang luas.

2. Dengan menerapkan model pengembangan rekayasa perangkat lunak jenis prototyping, website ini dapat memenuhi kebutuhan user sesuai dengan hasil kuesioner yang telah dirangkum pada bagian desain dan implementasi serta bagian uji coba.

3. Pengguna dapat menggunakan website media sosial yang telah dirancang secara efektif dan efisien dengan penerapan Facebook API untuk berbagi informasi kepada komunitas dunia tari.

4. Dengan adanya website ini, user dapat mengakses website media sosial dengan ruang lingkup yang sama dan mempunyai fitur-fitur yang dibutuhkan serta menyajikan tampilan yang user friendly.

\section{REFERENSI}

[1] Pengertian Forum. http://www.kanalinfo.web.id /2016/06/pengertian-forum.html. Diakses pada tanggal 10 Maret pukul 13.40 WIB.

[2] Cara Membuat Channel Youtube. http://www.endiid.com/2016/03/cara-membuat-channelyoutube-untuk.html Diakses pada tanggal 14 Maret 2017 pukul 10.20 WIB.

[3] http://www.programmableweb.com/api/facebook. Diakses tanggal 22 Februari 2017.

[4] Saputra, A. (2014). API Developer Buku Sakti Para Pengembang Web. Cirebon: CV. ASFA Solution.

[5] Nasrullah, R., (2015). Media Sosial: Perspektif Komunikasi, Budaya dan Sosioteknologi. Bandung: Simbiosa Rekatama Media. 